\title{
Isoflavone and protein content in soybeans grains submitted to flooding at different stages of development
}

\author{
Teor de isoflavonas e proteínas nos grãos de soja submetida ao alagamento em diferentes estádios de \\ desenvolvimento
}

\author{
Camila Argenta Fante ${ }^{\mathrm{I}}$ Patrícia de Fátima Pereira Goulart ${ }^{\mathrm{II}}$ José Donizeti Alves ${ }^{\mathrm{III}}$ \\ Paôla de Castro Henrique ${ }^{\mathrm{III}}$ Daniela Deitos Fries $^{\mathrm{IV}}$
}

\begin{abstract}
The stress imposed on plants by soil flooding constitutes a major barrier to growth and productivity. The identification of soybean varieties that produce higher levels of isoflavones, is necessary as soybeans have been used as human food to reduce risks of chronic diseases. Thus, this study was conducted with the objective of quantifying proteins and isoflavones in soybean cultivars subjected to flooding at various stages of development. The cultivars 'BRS267', 'BRS257' and 'BRS213' were subjected to 15 days of flooding, starting at the stages V6 and V8 and 11 days under stress starting at the stage R4. The proteins in the grain were extracted and quantified and analyzed by SDS-PAGE electrophoresis. Isoflavones were extracted, separated and quantified on HPLC. The electrophoretic analysis of the three cultivars under study revealed the same pattern of banding relative to the total protein regardless of the treatment. However, it was noted that flooding led to an increase in the total contents of isoflavones in the BRS 267 plants flooded in stage $R 4$, remaining constant in other cultivars.
\end{abstract}

Key words: Glycine max, hypoxia, functional food.

\section{RESUMO}

$O$ estresse imposto às plantas pelo alagamento do solo constitui uma barreira para o crescimento e produtividade destas. A identificação de cultivares de soja que possam produzir maior teor de isoflavonas torna-se necessária à medida que a soja vem sendo utilizada na alimentação humana e para redução dos riscos de doenças crônicas. Dessa forma, o presente estudo foi realizado com o objetivo de quantificar isoflavonas e proteínas em cultivares de soja submetidas ao alagamento em diferentes estádios de desenvolvimento. As cultivares 'BRS 267', 'BRS 257' e 'BRS 213' foram submetidas a 15 dias de alagamento, nos estádios V6 e V8 e 11 dias sob estresse, no estádio R4. As proteínas no grão foram extraídas e quantificadas e analisadas as eletroforeses em SDS-PAGE. Os isoflavonóides foram extraídos, separados e quantificados por HPLC. A análise por eletroforese das três cultivares revelou o mesmo padrão de bandas relativas às proteínas totais, independente do tratamento utilizado. O alagamento promoveu aumento no teor total de isoflavonas nas plantas alagadas no estádio R4 da cultivar 'BRS 267', permanecendo constante nas demais cultivares.

Palavras-chave: Glycine max, hipoxia, alimento funcional.

\section{INTRODUCTION}

In Brazil, the consumption of soybean as part of the human diet has received considerable attention because it is associated with reduced risk of chronic diseases and health maintenance. Beside its high protein content, soybean has, in its chemical composition isoflavones that are related to important biological properties (PARK et al., 2001; LUIS \& SAGRADO, 2006).

The soybean grains contain basically four different forms of isoflavones which are: glycosides (daidzin, genistin and glycitin) acetyl glycosides (acetyl-daidzin, acetyl-genistin and acetyl-glycitin),

'Departamento de Ciência dos Alimentos, Universidade Federal de Lavras (UFLA), CP 3037, 37200-000, Lavras, MG, Brasil. E-mail: camila.fante@gmail.com. *Autor para correspondência.

"Centro Universitário de Lavras (UNILAVRAS), Lavras, MG, Brasil.

"IIUniversidade Federal de Lavras (UFLA), Lavras, MG, Brasil.

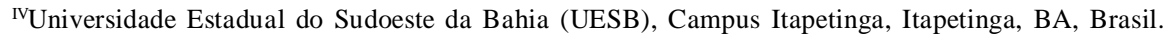


malonyl glycosides (malonyl-daidzin, malonyl-genistin and malonyl-glycitin) and the unconjugated structural form of aglycone (daidzein, genistein and glycitein). In soybeans, isoflavones occur naturally mainly on its malonyl and acetyl glycosides forms and to a lesser degree in the aglycone form (SCHWARTZ \& SONTAG, 2008). PARK et al. (2001) and GÓES-FAVONI et al. (2004) claimed that the malonyl glycosides forms are the most abundant in in natura soybean and that during grains processing, by high temperature and pressure, these forms are converted to the glycoside form.

The levels of isoflavones in soybeans grains vary with the stage of development. CARRÃOPANIZZI et al. (1999) showed that isoflavone accumulation, in general, occurs mainly during the grain filling stages (between 35 and 60 days after flowering). On the other hand, quantitative variations have been observed in certain fractions of isoflavones in other phases of crop development. Genistin and malonylgenistin, for example, tend to accumulate at the end of the period of development while daidzin and malonyldaidzin are present, in high concentrations, throughout the whole experimental period. Associated with quantitative/qualitative variations at certain stages of soybean development, levels of isoflavones may be influenced by environmental conditions (CARR ÃOPANIZZI et al., 2009). AL-TAWAHA et al. (2007) suggested that the soybean isoflavone levels are increased when plants are grown in areas subject to intermittent flooding. Agricultural practices such as planting date, fertilization, irrigation and weed control, in general, also increase the concentration of isoflavones in soybeans (AL-TAWAHA \& SEGUIN, 2006).

In Brazil, the exploitation of wetlands with species of economic importance still depends on the identification, not only of species that can effectively survive in the flooded soil, but also of those that can bring economic returns. In the case of soybeans, more studies are needed to gather knowledge, helping to select varieties capable of producing grains with high levels of isoflavones, since, its functional activity can bring additional benefits to human health.

Despite the knowledge on the benefits of isoflavones, little is known about their qualitatively and quantitatively variation regarding some environmental factors. Therefore, this study attempted to analyze the levels of isoflavones in three soybean cultivars, specific for human consumption, after the plants have been subjected to flooding at various stages of development.

\section{MATERIAL AND METHODS}

Plant material

It was used grains from soybean cultivars 'BRS 267', 'BRS 257' and 'BRS 213', which were specifically developed for human consumption. The grains were kindly provided by Embrapa Soja, Londrina, PR, Brazil.

Induction of treatments and experiment conduction

Seeds of the three soybean cultivars were sown in pots $(25 \mathrm{~cm}$ in diameter and $23 \mathrm{~cm}$ in, thus of $8 \mathrm{~L}$ capacity), containing as substrate, soil previously amended. After thinning, fertilization was performed as described by FANTE (2010). When plants reached the V6 stage (plants with six nodes), V8 (plants with eight nodes) or R4 (pod formation), they were subjected to flooding. For that, the pots were individually put into larger containers $(28 \mathrm{~cm}$ in diameter and $26 \mathrm{~cm}$ in high) without water flow. Then water was added, taking care to keep it $2.0 \mathrm{~cm}$ above the soil level. After 15 days of flooding at stages V6 and V8 and 11 days in the R4 stage, the plants were returned to the field capacity, which, together with the first, remained until grain harvest. For the control treatment, plants were irrigated daily, leaving the soil at field capacity.

Protein analysis

The proteins in the grains were extracted according to FANTE (2008). Protein quantification was performed following the method of BRADFORD (1976) and readings were performed on a spectrophotometer at $595 \mathrm{~nm}$. The results were calculated based on the standard BSA (bovine serum albumin) curve.

SDS-PAGE of total protein in the grains

The electrophoresis of the grain proteins was carried out using SDS-PAGE, (separating and concentrating gels at $12.5 \%$ and $6 \%$ polyacrylamide, respectively) according to FANTE (2008). After run, the gels were stained in a solution of Comassie Blue R250 overnight and bleached in a solution consisting of $5 \%$ ethanol, $10 \%$ acetic acid and $85 \%$ water, as indicated by ALFENAS (2006).

\section{Isoflavones analysis}

The extraction of isoflavones was second to FANTE (2008). The separation and quantification of the isoflavones was performed according to methodology recommended by BERHOW (2002), in a Water liquid chromatographer, model 2690, with an automatic sample injector. A reverse phase column type ODS C18 (YMC Pack ODS-AM Columm) was used, 
with $250 \mathrm{~mm}$ long $\mathrm{x} 0.4 \mathrm{~mm}$ internal diameter, $5 \mu \mathrm{m}$ particles. For separation of the isoflavones, it was adopted a binary linear gradient system as FANTE (2008). For the detection of the isoflavones, it was used the Waters array detector of photo diode, model 996, set to the wavelength equal to $260 \mathrm{~nm}$. The identification of peaks corresponding to each one of the isoflavones, daidzin, daidzein, genistin and genistein standards, all from Sigma, used dissolved in methanol (HPLC degree).

Experimental design and statistical analysis

The experiment was carried out using a randomized block design with three replications. Results were analyzed by an analysis of variance (ANOVA) and Tukey's tests, when appropriate, were performed using the statistical software Sisvar (FERREIRA, 2000).

\section{RESULTS AND DISCUSSION}

Flooding, not only caused morphological and biochemical changes in the plants (FANTE et al., 2010), but also caused quantitative and qualitative alterations in the biochemical composition of the grains. The protein content of the 'BRS 267' cultivar was dramatically decreased when plants were flooded, at all stages of development, when compared to the control and to the other cultivars (Figure 1). It was also noted that protein levels on the other cultivars, 'BRS 257' and 'BRS 213', when flooded, were altered only in the R4 stage, with smaller and higher levels, respectively. According to MINUZZI et al. (2009) the protein content of soybean seeds is heavily influenced by the environment, mainly during the grain filling. Unlikely, VEIGA et al. (2010) showed significant reduction in the grain composition as result of increased potassium content.

Despite the quantitative differences between treatments, the electrophoretic analysis of the proteins in the polyacrylamide gel revealed that the three cultivars, in all stages of development, have the same banding pattern, regardless of the treatment (Figure 2). Similar pattern was observed by VEIGA et al. (2010). The only observed difference is related to the presence of a band, of $95 \mathrm{kDa}$ molecular weight, in cultivar 'BRS267'. As studies dealing with electrophoresis of soybean grains proteins identified a lipoxygenase with molecular weight of $95 \mathrm{kDa}$ (JUNGHANS et al., 2004), it is possible that the band here verified corresponds to this protein. The catalytic action exerted by lipoxygenase on polyunsaturated fatty acids, linoleic and linolenic acid, of the soybean grains, is a major factor responsible for the appearance of carbonyl compounds, which promote the flavor of the grains (MARTINS et al., 2002). It is also important to highlight that the presence of a band with molecular weight of $160 \mathrm{kDa}$ in all analyzed samples (of all three cultivars). In general, in studies involving anaerobic stress, a band corresponding to $160 \mathrm{kDa}$, represents the alcohol dehydrogenase (BURDETTE \& ZEIKUS,

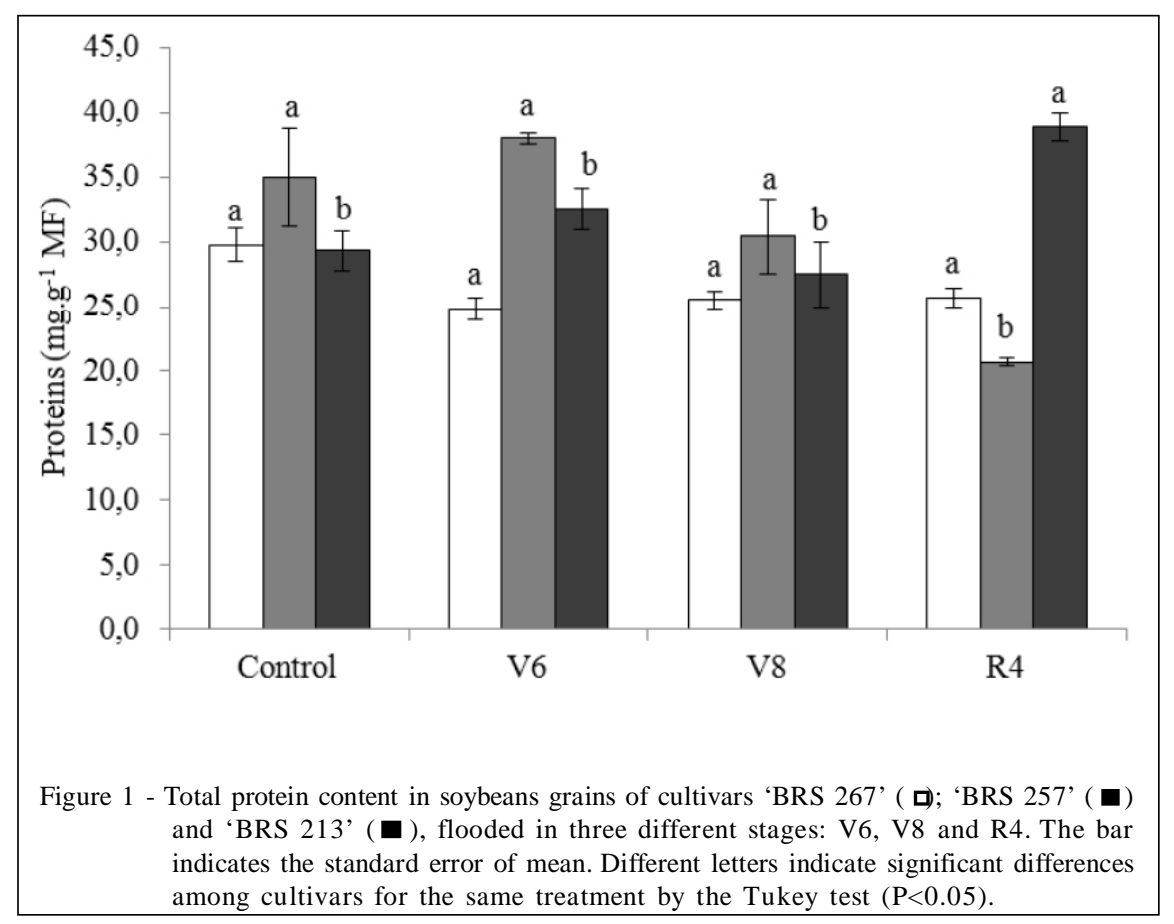

Ciência Rural, v.41, n.12, dez, 2011. 


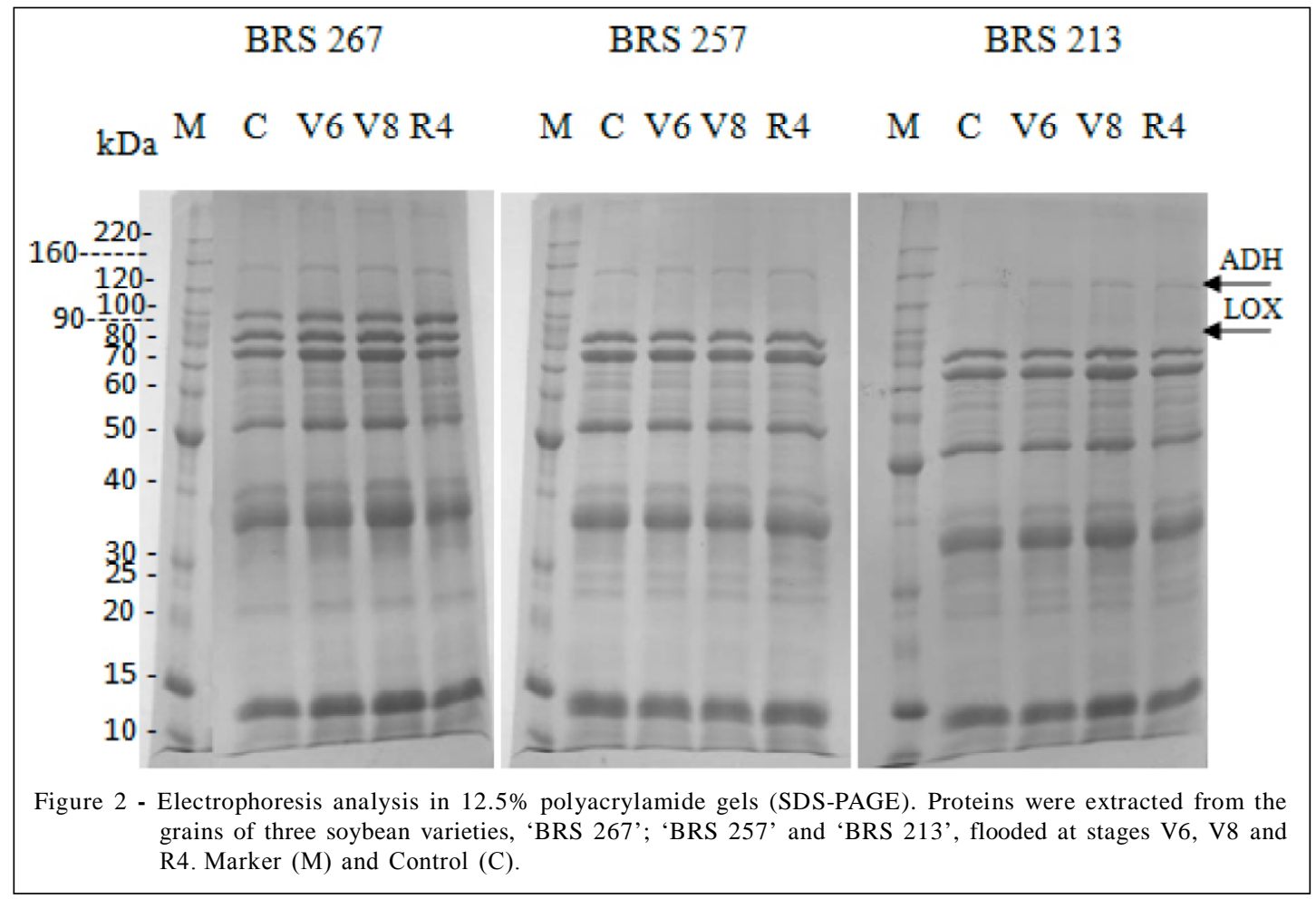

1994; ZHANG \& LIU, 2000). The ADH has been characterized as an anaerobic polypeptide, since its synthesis and activity are induced by flooding (ALVES et al., 2000). It is interesting to note that the flooding in $\mathrm{V} 6$ and $\mathrm{V} 8$ began when plants were still in the vegetative stage, represented by the presence of the developing sixth and eighth nodes, respectively, and ended in the early stages of the pod development. Thus, the presence of this enzyme within the same standards from those observed when plants were flooded in the reproductive stage $\mathrm{R} 4$, shows that the effects of anaerobic stress are permanent and are expressed in the grain, until the harvest.

Regarding the isoflavones, it was verified in the present study, changes in its concentration as a function of flooding, only on BRS 267 (Table 1). In this case, it is observed that the imposition of an anaerobic stress, on the R4 stage, promoted significant increases in the levels of daidzin, genistin, malonyl-daidzin and malonyl-genistin. As result of the increased concentration of these isoflavones, the soybeans flooded at this stage, presented higher total isoflavone content in the grains. Glycitin and malonyl-glycitin did not differ between treatments, while the aglycones daidzein and glycitein were not detected in grains of this variety. When plants were flooded at the V6 stage, genistein, the major responsible of the nutraceutical effect of the soybean, had a significant increase that averaged 3.2 times more if compared to the control plants. On the other cultivars, regardless of the stage where the stress was applied, the isoflavone content remained constant.

Of all isoflavones, the aglycones are those that promote more beneficial effects to human health. And in this case, with the exception of genistein, that increased when BRS 267 plants were flooded at the V6 stage, all others did not vary between treatments. However, in this research, it was noted that the types of isoflavones found in greater quantities in the grains of plants that were flooded at the R4 stage, were the glycosyl isoflavones and those that can be converted to aglycones, which are benefic to human health, during the industrial processing of grains. According to GRUN et al. (2001), in products derived from soybeans, like tofu and many others, when subjected to certain heat treatments, the malonyl forms suffer biotransformations and become aglycones, thus increasing the levels of the components responsible for its functional effects. Similarly, several authors report that the levels of aglycone isoflavones increased due to the processing and that the malonyl levels are reduced by cleavage of ester groups and by the heat that the extract is subjected to (PARK et al., 2001; CARRÃOPANIZZI et al., 2003; GÓES-FAVONI et al., 2004; 
Table 1 - Isoflavone content determined in soybean grains, subjected or not to flooding.

\begin{tabular}{|c|c|c|c|c|c|c|c|c|c|c|}
\hline \multicolumn{11}{|c|}{ Isoflavones (mg $\left.100 \mathrm{~g}^{-1}\right)$} \\
\hline \multirow[b]{2}{*}{ Cultivars } & \multicolumn{3}{|c|}{------Glycosil Isoflavones------ } & \multicolumn{3}{|c|}{-------Malonyl Isoflavones------- } & \multicolumn{3}{|c|}{--------Agliconas Isoflavonas-------- } & \multirow[b]{2}{*}{ Total } \\
\hline & Daidzin & Glycitin & Genistin & $\begin{array}{l}\text { Malonyl } \\
\text { Daidzin }\end{array}$ & $\begin{array}{l}\text { Malonyl } \\
\text { Glycitin }\end{array}$ & $\begin{array}{l}\text { Malonyl } \\
\text { Genistin }\end{array}$ & Daidzein & Glycitein & Genistein & \\
\hline \multicolumn{11}{|l|}{ 'BRS 267' } \\
\hline $\mathrm{C}$ & $22.6 b^{*}$ & $6.1 \mathrm{a}$ & $28.1 \mathrm{~b}$ & $142 \mathrm{ab}$ & $41.9 \mathrm{a}$ & $250.1 \mathrm{a}$ & ND & ND & $1.4 \mathrm{~b}$ & $503 b^{*}$ \\
\hline V6 & $19.3 \mathrm{~b}$ & $5.3 \mathrm{a}$ & $24.2 \mathrm{~b}$ & $86.3 \mathrm{~b}$ & $32.5 \mathrm{a}$ & $151.9 \mathrm{~b}$ & ND & ND & $4.5 \mathrm{a}$ & $373 \mathrm{~b}$ \\
\hline $\mathrm{V} 8$ & $24.7 \mathrm{~b}$ & $7.4 \mathrm{a}$ & $26.2 \mathrm{~b}$ & $94.2 \mathrm{~b}$ & $36.1 \mathrm{a}$ & $172.3 \mathrm{~b}$ & ND & ND & $\mathrm{ND} b$ & $361 \mathrm{~b}$ \\
\hline R4 & $43.2 \mathrm{a}$ & $9.3 \mathrm{a}$ & $45.9 \mathrm{a}$ & 190.9 a & $41.6 \mathrm{a}$ & $322.4 \mathrm{a}$ & ND & ND & $\mathrm{ND} b$ & 678 a \\
\hline \multicolumn{11}{|l|}{ 'BRS 257' } \\
\hline $\mathrm{C}$ & $27.1 \mathrm{a}$ & $10.3 \mathrm{a}$ & $24.1 \mathrm{a}$ & 202.9 a & $58.9 \mathrm{ab}$ & $260 \mathrm{a}$ & $1.7 \mathrm{a}$ & $5.1 \mathrm{a}$ & $1.2 \mathrm{a}$ & $602 \mathrm{a}$ \\
\hline V6 & $29.7 \mathrm{a}$ & $8.8 \mathrm{a}$ & $29.6 \mathrm{a}$ & $213.5 \mathrm{a}$ & $54.9 \mathrm{~b}$ & $309.2 \mathrm{a}$ & $1.5 \mathrm{a}$ & $5.9 \mathrm{a}$ & $0.9 \mathrm{a}$ & $654 \mathrm{a}$ \\
\hline V8 & $34.9 \mathrm{a}$ & $9.5 \mathrm{a}$ & $31.2 \mathrm{a}$ & $222.4 \mathrm{a}$ & $56.5 \mathrm{ab}$ & $307.1 \mathrm{a}$ & $1.9 \mathrm{a}$ & $6.6 \mathrm{a}$ & $0.9 \mathrm{a}$ & $671 \mathrm{a}$ \\
\hline R4 & $39.7 \mathrm{a}$ & $12.7 \mathrm{a}$ & $35.3 \mathrm{a}$ & $246.7 \mathrm{a}$ & $71.1 \mathrm{a}$ & $294.6 \mathrm{a}$ & $1.9 \mathrm{a}$ & $5.1 \mathrm{a}$ & $1.3 \mathrm{a}$ & $708 \mathrm{a}$ \\
\hline \multicolumn{11}{|l|}{ 'BRS 213’ } \\
\hline $\mathrm{C}$ & $20.0 \mathrm{a}$ & $3.2 \mathrm{a}$ & $25.4 \mathrm{a}$ & $215.7 \mathrm{a}$ & $34.8 \mathrm{a}$ & $310.8 \mathrm{a}$ & $2.6 \mathrm{a}$ & $5.5 \mathrm{a}$ & $1.7 \mathrm{a}$ & 619 a \\
\hline V6 & $32.9 \mathrm{a}$ & $6.0 \mathrm{a}$ & $27.5 \mathrm{a}$ & $231.1 \mathrm{a}$ & $36.4 \mathrm{a}$ & $308.1 \mathrm{a}$ & $2.0 \mathrm{a}$ & $4.1 \mathrm{a}$ & $0.9 \mathrm{a}$ & 649 a \\
\hline V8 & $22.5 \mathrm{a}$ & $5.9 \mathrm{a}$ & $21.1 \mathrm{a}$ & $190.9 \mathrm{ab}$ & $35.6 \mathrm{a}$ & $221.6 \mathrm{~b}$ & $1.8 \mathrm{a}$ & $4.5 \mathrm{a}$ & $1.2 \mathrm{a}$ & $505 \mathrm{a}$ \\
\hline R4 & $26.9 \mathrm{a}$ & $8.3 \mathrm{a}$ & $25.7 \mathrm{a}$ & $158.8 \mathrm{~b}$ & $49.7 \mathrm{a}$ & $247.3 \mathrm{ab}$ & $3.2 \mathrm{a}$ & $4.2 \mathrm{a}$ & $2.4 \mathrm{a}$ & $526 \mathrm{a}$ \\
\hline
\end{tabular}

*Means followed by the same lower case letters in the columns do not differed statistically by the Tukey test $(P=0.05)$. ND - not determine.

CIABOTTI et al., 2006). In this case, the anaerobic stress of the BRS 267 cultivar in V6 or R4 can improve the quality of soybeans grains, in a natural form or in vivo or by thermal processing, respectively.

\section{CONCLUSION}

The stress caused by the flooding on soybean plants, resulted in differences in protein content on the grains of cultivars 'BRS 257' and 'BRS 213 ' in the R4 stage. With regards to isoflavones content changes were observed on BRS 267, where genistein had a significant increase in the grains of plants flooded at the V6 stage. The glycosyl isoflavones forms, which can be converted to aglycones during the industrial processing, also increased in the grains of plants which were e flooded at the R4 stage.

\section{ACKNOWLEDGEMENTS}

The authors would like to thank the Conselho Nacional de Desenvolvimento Científico e Tecnológico (CNPq) and Fundação de Amparo a Pesquisa do Estado de Minas Gerais (FAPEMIG) for their financial support.

\section{REFERENCES}

ALFENAS, A.C. Eletroforese e marcadores bioquímicos em plantas e microorganismos. 2.ed. Viçosa: UFV, 2006. $627 \mathrm{p}$.
AL-TAWAHA, A.M.; SEGUIN, P. Effects of seeding date, row spacing, and weeds on soybean seed isoflavone concentration. Canadian Journal of Plant Science, Ottawa, v.86, n.4, p.1079-1082, 2006. Available from: <http://ginkgo.cisti.nrc.ca/ RPAS/rpv $? \mathrm{hm}=$ HInit $\&$ journal $=$ cjps $\&$ volume $=86 \&$ afpf $=\mathrm{P} 06-$ 043.pdf $>$. Accessed: Mar. 07, 2011. doi: 10.4141/P06-043.

AL-TAWAHA, A.M. et al. Irrigation level affects isoflavone concentration of early maturing soya bean cultivars. Journal Agronomy \& Crop Science, Oxford, v.193, n.4, p.238-246, 2007. Available from: <http://onlinelibrary.wiley.com/doi/ 10.1111/j.1439-037X.2007.00263.x/pdf>. Accessed: Mar. 06, 2011. doi: 10.1111/j.1439-037X.2007.00263.x.

ALVES, J.D. et al. Mecanismo de tolerância de plantas ao alagamento. Universa, Brasília, v.8, p.221-242, 2000. Available from: <http:// www.scielo.br/scieloOrg/php/reflinks.php? refpid=S0006$8705200700010000100002 \&$ pid = S 0006 87052007000100001\&lng=en>. Accessed: Mar. 07, 2011.

BERHOW, M.A. Modern analytical techniques for flavonoid determination. In: BUSLIG, B.S.; MANTHEY, J.A. (Ed.). Flavonoids in the living cell. New York: Klusher Academic, 2002. p.61-76. (Advances in Experimental Medicine and Biology, v. 505). Available from: <http://books.google.com.br/ books?hl=pt-BR\&lr=\&id=W8I0Mcp 1 irkC \&oi $=$ fnd $\&$ pg $=P$ A61\&dq=Modern+analytical+techniques+for+flavonoid + de termination \& o t $s=j$ d j P g 1 P C T \& s i g $=B$ 72Dtdv_JdnRcSy7eb8E0NAoFDA\#v=onepage $\& \mathrm{q}=$ Modern $\% 2$ 0 a na 1 y t i c a $1 \% 20 \mathrm{techn}$ i q e s $\% 20 \mathrm{for}$ $\% 20$ flavonoid\%20determination\&f=false >. Accessed: Mar. 07, 2011.

BRADFORD, M.M. A rapid and sensitive method for the quantitation of microgram quantities of protein utilizing the principle of protein-dye binding. Analytical Biochemistry, 
New York, v.72, n.1/2, p.248-258, 1976. Available from: <http://www.ciens.ucv.ve:8080/generador/sites/lab-bioq-gen/ archivos/Bradford\%201976.pdf>. Accessed: Mar. 07, 2011.

BURDETTE, D.; ZEIKUS, J.G. Purification of acetaldehyde dehydrogenase and alcohol dehydrogenases from Thermoanaerobacter ethanolicus $39 \mathrm{E}$ and characterization of the secondary-alcohol dehydrogenase $\left(2^{\circ} \mathrm{Adh}\right)$ as a bifunctional alcohol dehydrogenase-acetyl-CoA reductive thioesterase. Biochemical Journal, London, v.302, p.163-170, 1994. Available from: <http://www.ncbi.nlm.nih.gov/pmc/articles/ PMC1137204/pdf/biochemj00081-0166.pdf>. Accessed: Jun. 09, 2011

CARRÃO-PANIZZI, M.C. et al. Effects of genetics and environment on isoflavone contento $f$ soybean from different regions of Brazil. Pesquisa Agropecuária Brasileira, Brasília, v.34, n.10, p.1787-1795, 1999. Available from: <http:/ /www.scielo.br/pdf/pab/v34n10/7178.pdf >. Accessed: Mar. 06, 2011. doi: 10.1590/S0100-204X1999001000004

CARRÃO-PANIZZI, M.C. et al. Efeitos de genótipos, ambientes e de tratamentos hidrotérmicos na concentração de isoflavonas agliconas em grãos de soja. Pesquisa Agropecuária Brasileira, Brasília, v.38, n.8, p.897-902, 2003. Available from: <http://www.scielo.br/pdf/pab/v38n8/18229.pdf>. Accessed: Mar. 06, 2011. doi: 10.1590/S0100204X2003000800001.

CARRÃO-PANIZZI, M.C. et al. Environmental and genetic variation of isoflavone content of soybean seeds grown in Brazil. Pesquisa Agropecuária Brasileira, Brasília, v.44, n.11, p.1444-1451, 2009. Available from: <http://www.scielo.br/pdf/ pab/v44n11/11.pdf>. Accessed: Mar. 06, 2011. doi: 10.1590/ S0100-204X2009001100011.

CIABOTTI, S. et al. Avaliações químicas e bioquímicas dos grãos, extratos e tofus de soja comum e de soja livre de lipoxigenase. Ciência e Agrotecnologia, Lavras, v.30, n.5, p.920-929, 2006. Available from: <http://www.scielo.br/pdf/ cagro/v30n5/v30n5a15.pdf>. Accessed: Mar. 06, 2011. doi: 10.1590/S1413-70542006000500015.

LUIS, D.A; SAGRADO, R.A. Efectos de la soja en la salud de la mujer menopáusica. Revista Clinica Española, Barcelona, v.206, n.4, p.205-207, 2006. Available from: <http:// www.refdoc.fr/Detailnotice? cpsidt $=17837474 \&$ traduire $=f r>$. Accessed: Mar. 07, 2011. doi: 35400014252226.0120.

FANTE, C.A. et al. Respostas fisiológicas em cultivares de soja submetidas ao alagamento em diferentes estádios. Bragantia, Campinas, v.69, n.2, p.249-252, 2010. Available from: <http:/ /www.scielo.br/pdf/brag/v69n2/01.pdf >. Accessed: Mar. 07, 2011. doi: 10.1590/S0006-87052010000200001.

FANTE, C.A. Teores de isoflavonas no grão e respostas fisiológicas em cultivares de soja submetidas ao alagamento, em diferentes estádios. 2008. 48f. Dissertação (Mestrado em Agronomia/Fisiologia Vegetal) Universidade Federal de Lavras, Lavras, MG

FERREIRA, D.F. Análises estatísticas por meio do SISVAR para windows versão 4.0. In: REUNIÃO ANUAL DA REGIÃO
BRASILEIRA DA SOCIEDADE INTERNACIONAL DE BIOMETRIA, 45., 2000, São Carlos. Resumos... São Carlos: UFSCar, 2000. p.235.

GÓES-FAVONI, S.P. et al. Isoflavonas em produtos comerciais de soja. Ciência e Tecnologia de Alimentos, Campinas, v.24, n.4, p.582-586, 2004. Available from: <http:// www.scielo.br/pdf/cta/v24n4/a17v24n4.pdf>. Accessed: Mar.07, 2011. doi: 10.1590/S0101-20612004000400017.

GRUN, I.U. et al. Changes in the profile of genistein, daidzein, and their conjugates during thermal processing of tofu. Journal of Agriculture and Food Chemistry, Washington, v.49, n.6, p.2839-2843, 2001. Available from: <http://pubs.acs.org/doi/ pdfplus/10.1021/jf010028\%2B>. Accessed: Mar. 07, 2011. doi: $10.1021 / \mathrm{jf} 010028+$

JUNGHANS, T.G. et al. Lipoxygenase activities during development of root and nodule of soybean. Pesquisa Agropecuária Brasileira, Brasília, v.39, n.7, p.625-630, 2004. Available from: <http://www.scielo.br/pdf/pab/v39n7/ 21303.pdf>. Accessed: Jun. 09, 2011 doi: 10.1590/S0100204X2004000700002.

MARTINS, C.A.O. et al. Efeito da eliminação genética das lipoxigenases das sementes sobre as características agronômicas da soja. Pesquisa Agropecuária Brasileira, Brasília, v.37, n.10, p.1389-1398, 2002. Available from: <http://www.scielo.br/ pdf/pab/v37n10/13217.pdf>. Accessed: Mar. 06, 2011. doi: 10.1590/S0100-204X2002001000006.

MINUZZI, A. et al. Rendimento, teores de óleo e proteínas de quatro cultivares de soja, produzidas em dois locais no estado do Mato Grosso do Sul. Ciência e Agrotecnologia, Lavras, v.33, n.4, p.1810-1817, 2009. Available from: <http:// www.scielo.br/pdf/cagro/v33n4/a15v33n4.pdf>. Accessed: Mar. 06, 2011. doi: 10.1590/S1413-70542009000400015.

PARK, Y.K. et al. Avaliação do teor de isoflavonas em soja brasileira. Ciência y Tecnologia Alimentaria, Reynosa, v.3, n.3, p.156-160, 2001. Available from: <http:// redalyc.uaemex.mx/pdf/724/72430305.pdf $>$. Accessed: Mar. 07, 2011

SCHWARTZ, H.; SONTAG, G. Determination of isoflavones in nutritional supplements by HPLC with coulometric electrode array detection. Monatshefte für Chemie, v.139, p.865872, 2008. Disponível em: <http://www.springerlink.com/ content/e605272043265120/fulltext.pdf>. Accessed:Mar. 07, 2011. doi: 10.1007/s00706-008-0879-3.

VEIGA, A.D. et al. Influence of potassium and liming on chemical composition, physiological quality and enzyme activities of soybean seeds. Ciência e Agrotecnologia, Lavras, v.34, n.4, p.953-960, 2010. Available from: <http:// www.scielo.br/pdf/cagro/v34n4/v34n4a22.pdf>. Accessed: Mar. 07, 2011. doi: 10.1590/S1413-70542010000400022.

ZHANG, Q.; LIU, H. Studies od UDP-Galactopyranose mutase from Escherichia coli: An unusual role of reduced FAD in its catalysis. Journal American Chemical Society, Washington, v.122, n.38, p.9065-9070, 2000. Available from: http:// pubs.acs.org/doi/pdfplus/10.1021/ja001333z. Accessed: Jun. 09, 2011. doi: $10.1021 / \mathrm{ja} 001333 \mathrm{zCCC}$. 